\title{
Worries About His Future
}

\author{
Xinhui Chen
}

\section{Interview with Mr. QJ's Family}

QJ, male, born in 1984. Has an elder sister. Has severe intellectual disability. Graduated from a mainstream school. Started working at Shanghai Papa John's in 2010.

Interviewees: QJ's parents and QJ's aunt

Interviewer and writer: Xinhui Chen

Interview dates: October 27 and December 9, 2016

Interview place: QJ's home

\section{Government-Mandated Relocation from Pudong Airport}

QI: would like to start by getting some background information. How many people are there in your family?

QJ's mother: Four, but my daughter is married with an 11-year-old son. I am retired. I would like to find some work, but my health isn't good.

QJ's father: There are four people in our family and my daughter is older than little QJ. Little QJ's mom has diabetes and high blood pressure and has to take medication all the time. Even with insurance coverage, we can barely pay for her medication

Q: How did you two meet?

QJ's mother: Someone introduced us. We were not the kind to date around.

QJ's father: I was local whereas she was sent by the government to work in the countryside. We came together because we kind of clicked.

\footnotetext{
X. Chen $(\varangle)$

East China Normal University, 3663 Zhongshan Bei Ro, Shanghai 200062, China 
QJ's aunt: Both my sister and I were sent by the government to work in the countryside while we were still single, and we ended up working on the same farm. I got married first and she followed. We were on the same boat financially and we both started from scratch. We went out to work and saved every penny we made. People were building their own houses in the countryside, so we built our houses which were kind of alike. Back then, we put everything we had into the houses. The government relocated us in 1996. I got a three-bedroom apartment on the sixth floor, and because of her son's condition, the government allowed her to take a ground-floor apartment.

Q: How long did you date before getting married?

QJ's father: About 2 years.

Q: How long did you wait till you had your first child?

QJ's mother: About 2 years.

Q: What about QJ?

QJ's mother: Little QJ is 2 years younger than his sister.

Q: What did you do before retiring?

QJ's father: I used to have a very ordinary job, security. There are a lot of companies close to Pudong Airport and they all needed security people. We used to make a living farming and developing barren land, but we lost our land to the airport. So we registered with the Labor Division and I was hired for my looks. I worked for 6 or 7 years and qualified for a pension. Then the manager told me, "We would have kept you were it not for your age." He then suggested that I find work somewhere else, which I did.

QJ's mother: I used to work in a company. After the government-mandated relocation, I started receiving the pension early, ${ }^{1}$ at age 40 , and have been on it since then. I worked for several years at a private company and didn't continue because of my health.

Q: What did your early pension have to do with government-mandated relocation?

QJ's mother: Back then, you were eligible for a pension at 40 . I happened to be 40 , or maybe 45 , I can't quite remember.

QJ's father: Most people in our neighborhood and in the neighborhood over there retired early for pension. The government wanted our land for the first runway of Shanghai's international airport and we were the first group to receive early pensions from the government.

QJ's mother: We were a family of four back then, so we qualified for this apartment measuring less than $100 \mathrm{~m}^{2}$.

Q: How much was your pension when you first started receiving it?

QJ's mother: It was less than 200 yuan about 20 years ago, only around 180 yuan.

\footnotetext{
${ }^{1}$ Early pension: Under a preferential policy, residents relocated by the government could retire early and receive a pension.
} 


\section{A Cute, Starry-Eyed Child}

Q: Did anything unusual happen when QJ's mom was pregnant?

QJ's aunt: QJ's dad was herding ducks for someone else on the beach. Shanghai No. 2 Plastics Plant was practicing shooting and a bullet pierced his hand. The plant paid him nominal compensation. Soon after the accident, little QJ's mom got pregnant with him. I believe the gun wound did something. Or maybe it's genetic, because little QJ's dad's younger brother has some intellectual disability. Little QJ's grandpa and uncle tend to repeat what they say, but not as many times as he does. They usually stop after repeating once or twice.

Q: Did you do anything special in order to have a boy the second time around?

QJ's mother: I didn't eat anything special. There wasn't much to eat back then. I barely had enough to eat.

QJ's aunt: You did eat. She had a girl the first time, so did I. Then I had a boy the second time around. Before she got pregnant with the second one, I told her that what she ate could affect the gender of the baby, which I read in a magazine. So I told her, "Don't eat meat or peanuts or desserts, just eat vegetables." She followed my instructions and only ate what I believed was good for her.

QJ's father: There were quite a few families with a boy and a girl, it was quite normal to have two kids like us.

Q: Was the one-child policy already in effect then?

QJ's mother: It was and there was a penalty of 700 or 800 yuan for having a second child, which was a fortune back then. It was a little over 80 yuan for the first year, then the penalty was increased at the rate of 300 yuan per year and reached 600 yuan after 2 years. Also, benefits that came with land ownership were taken away, which brought the total penalty to around 1,000 yuan.

Q: When QJ was a toddler, was there anything different about the way he talked or walked?

QJ's aunt: Not really. He had big eyes and was really cute and not afraid of strangers. But his head seemed to be drooping when he was young.

QJ's mother: His head wasn't exactly drooping, but by age three or four, he seemed to have lost interest in playing.

Q: What did QJ like to play with when he was young? Like blocks or toy cars?

QJ's mother: He liked them all.

QJ's aunt: He wanted to play with those, but his parents couldn't spare the money to buy them for him.

QJ's father: He really wanted to play with those.

QJ's aunt: My son is 2 years older than little QJ. Wherever he went, he wanted to buy toy cars and toy planes. I did buy them for him but not every time. Sometimes you had to give the kids what they wanted; you couldn't deny them every single time.

QJ's father: Back then, life was hard for everyone. The grown-ups didn't make a lot by farming or working in a factory. QJ's aunt was like us and started with nothing. We had to build our own houses, so we could hardly spare the money to buy the kids toys. Life has improved now, of course, and it's easy to buy the kids toy guns, toy 
cars, and toy planes. You want your kid to grow up to be someone, so if other kids have toy planes, your kid must have one, and if other kids have balls, your kid must have one too. All for the sake of intellectual development.

Q: Did he go to a regular preschool?

QJ's aunt: He never went to preschool. Preschool wasn't for everyone back then. We were living even further away from the city than Pudong Airport, which was like a forgotten corner. My sister and I were sent there to work from Yangjing. After we had kids, there was no daycare or preschool, so we had to keep the kids locked up at home. Once the kids were older and couldn't be kept at home anymore, we just took them to the field with us in the morning. We would lay some cover on the ground for them and an umbrella over their heads. That's how they were brought up.

\section{Being Bullied All the Way and Having to Quit School Early}

Q: How old was QJ when you realized that he couldn't keep up with other kids?

QJ's aunt: Since he started elementary school. I believe that the bullying he suffered at school made him the way he is. Also, he hadn't received proper guidance at home. When he was in elementary school, he would be bullied and would tell me, "Aunt, this kid hit me." If he went home and told his parents, his parents would brush it off as they were too busy working in the field. So he could only tell me. I would ask him exactly who had hit him and he would say he didn't know. So I would ask if he was making it up and that would give him pause. But after a little while, he would come and tell me again that someone had hit him.

He was always saying things like that. I actually believe that no one really tried to hit him. Someone might have just bumped into him or wanted to tease him seeing that he was a little slow. Or maybe someone did deliberately hit him pretty hard on the head because he looked like he could easily be bullied.

QJ's mother: He wouldn't tell us if he was bullied. Now he won't tell us anything. His classmates all bullied him, but he never said anything once he got home. On the way home, a classmate hit little QJ. I questioned the kid about it and he denied it, and his mom denied it too. She was not someone to reason with.

Q: Have you ever taken him to see a doctor?

QJ's mother: Yes, when he was seven or eight. At Shanghai Children's Hospital, the doctor gave him a pen and asked him if he knew anything about it, and he said he did. So the doctor thought I was being paranoid. I told the doctor, "I feel that my son isn't doing as well as other kids." I took him to the doctor several times and every time the doctor would say, "There's nothing wrong with him. You are not making sense. He knows everything. Whatever you show him, he knows what it is."

QJ's aunt: You should have asked me along the very first time. She never consulted me on anything till things got serious. In my opinion, even though QJ is already in his thirties, he could still use some guidance and we can't just give up on him. He will definitely improve with the right guidance.

Q: Have you ever taken QJ to any special place for an IQ test? 
QJ's father: We did take him to a major hospital, No. 8 People's Hospital, and the doctor said that his IQ is a little low.

Q: Was there a more specific diagnosis?

QJ's mother: He didn't give any specific diagnosis. He just said that QJ didn't have any intellectual disability.

Q: Did you ever go back to the hospital?

QJ's mother: No.

Q: At elementary school, which subject did QJ do better in?

QJ's aunt: He didn't do well in math, that I know.

QJ's mother: He couldn't draw. Except for Chinese, he didn't do well in anything.

QJ's father: He was doing only slightly better in Chinese, better than in math. $\mathrm{He}$ was failing math.

Q: At elementary school, how did QJ communicate with the teacher?

QJ's aunt: There was hardly any communication at all. The teacher basically put him in a corner and ignored him.

QJ's mother: The teacher not only ignored him but also bullied him. When it rained and the window at the back of the classroom got broken, the teacher put a blackboard there and asked him to hold the board.

Q: Did QJ tell you this when he came home?

QJ's mother: No. His classmate did.

Q: Where was he seated?

QJ's mother: Last row, in the corner.

Q: Have you been to any parent-teacher meetings?

QJ's aunt: I went several times. I don't know how many times his mom went.

QJ's mother: I went twice.

QJ's father: I seldom went.

Q: Which grade was he in when QJ's aunt went?

QJ's aunt: Either third or fourth grade. Then I stopped going. Parent-teacher meetings were not frequent back then.

Q: Did the teacher communicate with either of you at the parent-teacher meeting?

QJ's mother: There was no communication whatsoever. I was invisible and had nothing to say anyway. The teacher just said that my kid was useless.

QJ's aunt: I communicated to a degree. The teacher said that QJ used the empty classroom upstairs as a bathroom, and I asked why he would even go upstairs in the first place. As it turned out, some classmate had tricked him into it. That was a failure on the teacher's part. Something was amiss in the kids' moral education. I asked little QJ why he would do what he did. The teacher took a kid from the class upstairs to clean up the classroom and told little QJ not to come to school anymore as he had made such a mess there. He repeated first grade, then moved up with no more disruption.

QJ's mother: He repeated first grade, then continued as an unregistered student till the end of elementary school. Being an unregistered student meant that he sat in the last row of the classroom and was not treated as an official student.

Q: How was the decision made to switch him to unregistered student status? 
QJ's mother: I ran into his teacher outside school who told me, "It makes no sense for him to keep repeating grades. Why don't we just have him move up?"

Q: Did QJ still do homework after he started second grade?

QJ's mother: He did, but he wasn't taking it seriously.

Q: Did the teacher check his homework?

Q: Yes, and almost everything was marked wrong.

Q: QJ went to two different elementary schools, right?

QJ's mother: Yes, because of our relocation. The elementary school was part of the relocation program, so we switched from San Xing Elementary School to Jiang Zhen Elementary School.

Q: How much did you pay for elementary school back then?

QJ's mother: Less than 100 yuan per semester.

Q: When he was at elementary school, did you help him with his homework after school?

QJ's mother: His sister and he did homework together. We were very busy then, having to sell vegetables after growing them.

QJ's aunt: The two of them hadn't had a lot of education themselves, so they couldn't help with homework. And it wasn't effective for his sister to help him either.

QJ's mother: She was doing so-so at school anyway.

QJ's father: It was frustrating for us, because his mom had never been to school. My dad sent me to school when I was young, but I wasn't a good student. We should have helped my daughter with her homework when she was going to school, but we didn't have the ability. So she stayed up past 10 p.m. every day doing homework.

Q: How did his sister usually take care of him?

QJ's mother: His sister was very close to him, keeping him next to her, cooking for him, doing his laundry and basically everything else for him. They would go to school together and come home together, unless she stayed late at school in which case he would come home first. If he went out to play, she would go out and look for him and tell him, "Mom will be mad at me if she comes home to find you not at home." Little QJ said that she was like a mom to him. But she didn't help him much with his homework because she had to do her own homework and help around the house. She started cooking when she was four or five. Their dad was working in Shanghai and only came home once a month. I was working too, in addition to managing more than a dozen acres of land. I also had to catch crabs from the ocean to sell in the market. Then their dad got a job with the ocean farm and moved back.

QJ's aunt: His sister is very nice. At home, his dad talks a lot and his mom seldom talks. There's no one little QJ can communicate with.

Q: At elementary school, did QJ go out and play with classmates after school?

QJ's mother: His sister kept him at home and wouldn't let him out.

QJ's father: What happened then was this: His mom had to work and so did I-we literally had to work from dawn till dusk. My mom passed away at 60, so there was no one to help take care of the kids. It was pretty sad.

$\mathrm{Q}$ : Was there any sports that QJ liked?

QJ's father: Not really. 
Q: Were there any kids the same age in the neighborhood?

QJ's father: There was one.

Q: Were the two of them close?

QJ's father: So-so. The grown-ups would tell them to play with each other, and they did when we were not around.

Q: How old was QJ when he graduated from elementary school?

QJ's mother: Fourteen or fifteen.

Q: Which school did he go to after graduating from elementary school?

QJ's mother: There was no school to go to. No one told us where to go.

Q: Why didn't he go on to middle school?

QJ's mother: We were told not to have him continue schooling. He failed the middle school entrance exam. After graduating from elementary school, he should have received a notice to enroll in a middle school, but he didn't.

QJ's father: Both of us went to the middle school to inquire and the first thing we were told was, "We won't take this kid." We were crushed hearing this. We wanted him to continue schooling even if we had to borrow money from relatives to do so, but the principal rejected us.

QJ's mother: The middle school said that it wouldn't take unregistered students. We were not allowed to submit his name, so we didn't.

Q: After QJ graduated from elementary school, did you know that there were special education schools set up specifically for special-needs children?

QJ's mother: Yeah.

QJ's aunt: I reminded her saying, "Go look up those schools and send the kid there to learn something. It will help him get a job later on. Failing that, it's still good for him to have a chance to communicate with other people." She might have asked around and decided that the fees were high, so she dismissed those schools.

QJ's mother: The schools were far away. I was retired and working part-time at the airport duty-free shop, and I had no time to take him to any of those schools. Back then, there were no such schools in Pudong New District-they were all located in urban Shanghai. There was also the transportation fee. We made little money back then, so we didn't send him to any of those schools.

Q: Which school did you look into?

QJ's mother: The one that was close to Gaoqiao.

Q: How much were the fees?

QJ's mother: I didn't ask. I just heard that they were pretty high.

QJ's aunt: My nephew isn't really that slow. It's just that he grew up being looked down upon and discriminated against. People thought he was slow, so he has come to believe that he is slow. But he isn't. From an early age on, he could recognize all those words in books and on street signs. And he has beautiful handwriting. He just can't do math. If you ask him to do addition, multiplication, or subtraction, his response is extremely slow. 


\section{Changing Jobs Frequently}

Q: What did QJ do after graduating from elementary school?

QJ's mother: He stayed home.

Q: What did he do at home all day?

QJ's mother: Nothing much except playing games and watching TV. We bought him a handheld gaming device for 800 yuan. He insisted on having it and stayed home to play it.

Q: What was his daily schedule like?

QJ's mother: He didn't exactly sleep in. He would get up around seven or eight and have the breakfast I made for him before playing on his computer. For lunch, he would eat leftovers from breakfast, and I would cook him dinner after I got home. Sometimes he would go out for some fresh air after dinner and come back to play on the computer again, and sometimes he would be on the computer until after midnight.

QJ's father: Just like kids nowadays who play on the computer all day long.

Q: Do you think QJ was happy during that period of time?

QJ's mother: He was very happy when he was young-he's never happy now that he's grown up.

Q: After graduation, would QJ go out for fun besides staying home?

QJ's mother: He would, but he always came back after just a little while.

QJ's aunt: When he was young, he would go out with no specific plan. Now he seems to have specific places to go every week.

Q: When did QJ start looking for a job?

QJ's mother: After he turned 20.

Q: Did he find any jobs before the one at Papa John's?

QJ's mother: He did land three or four jobs, by registering with the Bureau of Labor Services.

QJ's aunt: He started working pretty early, when he was around 20. Someone got him a job at the airport but it didn't last long. So since joining Papa John's, he is constantly worried about being laid off. It's always on his mind and he keeps saying it out loud.

One time when he was still looking for a job and wasn't getting anywhere, he totally gave up on himself. So he stood on the bridge and talked to himself non-stop. Some passersby felt that there was something wrong with him and called 110 for fear that he might jump into the river. He was picked up by the police and taken to the police station. The police asked him his home phone number and he wouldn't tell them. He wouldn't tell the police his mom's phone number either, because he didn't know what would happen once his mom took him home. When the police pressed him, he had no choice but to give out my number. The police called me and asked me to identify myself, which I did. Then I was told that QJ was at the police station. I asked why and what he had done to end up there. And I was told that he had done nothing wrong and that someone from the family had to pick him up and take him home.

Q: What kind of jobs did QJ have? 
QJ's mother: He worked at the airport and at warehouses too, more than once. At two terminal restaurants at the airport, one of which was operated by a famous hotel in Shanghai. He just followed the chef around and passed him utensils. But he didn't do well. He also worked at moving and packaging things.

QJ's father: Yeah, he worked at the terminal restaurants and also moved things at the airport. The restaurant job was pretty decent. He was asked to separate big bowls from small ones, but he couldn't do it. He was asked to distribute food and not to distribute too much in case the boss got mad, but he couldn't do it. When he was laid off from the restaurant job, his mom and I almost cried, because it was a good job and close to home, but he just couldn't do it.

Q: All of the jobs QJ has had were at the airport, right?

QJ's mother: Right.

QJ's father: He felt that those workplaces were pretty nice, but the thing is that he should have tried harder to keep those jobs.

Q: Did he come home and tell you that he enjoyed working at those jobs?

QJ's mother: He did enjoy it, but no one had wanted to keep him.

Q: How long did he work at those jobs approximately?

QJ's mother: Six months or so. He couldn't get along with people, so he was laid off.

QJ's father: Six months or not even that long at some jobs. This Papa John's job has lasted the longest so far.

QJ's aunt: Six months or several months, and when the managers saw the way he was...

QJ's mother: At first he was hired because of his build. Once he was hired, he couldn't do the job well, so he was laid off. Sometimes he was laid off probably because he couldn't get along with the co-workers.

Q: Did QJ show any intention of sharing with you after he got his first paycheck?

QJ's mother: He was happy, saying, "I got paid and I got this much." He went to get the money himself.

Q: How does QJ spend the money he makes?

QJ's mother: Not sure, probably on food for himself. One time he bought a box of milk for his grandma and told her that the milk was pretty good.

QJ's aunt: Not really. He visited me often, so I told him jokingly that kids his generation should buy something for their grandma once they got their first paycheck. There was another time when he bought two boxes of pizza, probably because the store manager told him that he could get a discount if the pizzas were intended as gifts to his relatives. So he bought two, one for each uncle, and he brought the pizzas to the uncles' houses.

QJ's mother: I didn't know about that. I didn't know till you just told us.

QJ's aunt: She doesn't get along with one of my sisters-in-law, so her son bought the pizzas without consulting her and told his uncles not to tell his parents. That's why I had kept it a secret till just now.

Q: Has he ever bought his parents anything?

QJ's mother: Nothing. 


\section{Worrying Obsessively About Losing Job}

\section{Q: How did QJ land this job at Papa John's?}

QJ's mother: He found it online himself. He can do a lot online but nothing around the house. He wanted this job a lot, which he has been working at for about 7 or 8 years, ever since the restaurant opened.

Q: Did he go to the Papa John's interview by himself or did you go with him?

QJ's father: We went with him. He wouldn't have known how to go by himself, because his mom and I had always gone with him. One time, the three of us went together for a job interview and the secretary questioned what was wrong with him since he had to have his parents go with him.

QJ's aunt: You should have kept out of sight of the manager.

QJ's father: The manager did say that there were dozens of job applicants at the interview and none of their parents went with them. Especially as we are local and lived close by and knew our way around. Once the parents showed up, people would have questions.

QJ's aunt: You hadn't known better. You should have just stepped outside and stayed away.

Q: Did you sit in on QJ's interview?

QJ's father: No, he was interviewed inside and we waited for him outside.

QJ's aunt: He went to a lot of job interviews and watched when other people were interviewed, so he knew how to do it. If he had been the first one to be interviewed, he would have been in trouble. A lot of employers interviewed all applicants in the same room, so he could stay in the back of the line and listen to what other people said. But fancier employers interviewed in a separate room, in which case he had no chance to listen.

Q: Had anyone ever taught QJ how to go to an interview?

QJ's aunt: I did. I also taught him what to say on a date.

Q: How is this Papa John's job?

QJ's mother: When he started this job, he really wanted to keep it, but I didn't want him to. He had been receiving a low-income subsidy ${ }^{2}$ which he lost once he started working at Papa John's, and what he made at Papa John's couldn't even cover grocery expenses. His starting salary there was 800 yuan whereas the low-income subsidy from the Civil Affairs Bureau was 500 or 600 yuan. It's not a good deal if you really think about it. You stay home not doing anything and still receive 500 or 600 yuan, or you go out to work for not much more money but have to pay extra for transportation and meals and whatnot, so it's better that you just stay home.

He wouldn't listen to me and even threatened me with his life. He said, "What do you mean by not wanting me to keep this job? I found this job myself on the Internet." So he cried and insisted on keeping this job. The leader from the Community Affairs Committee said, "Just let him continue and see what happens. You may not think that this extra 200 yuan is worth the effort, but it's not good to keep your son at home.

\footnotetext{
${ }^{2}$ Low-income subsidy: The local government subsidizes residents whose average household income falls below that required for minimum-standard living in that area.
} 
He needs to go out to work and to have human interaction." I changed my mind after thinking about what he said. At first QJ was all motivated and went to work very early every day. But he has been wanting to quit these last couple of years. He got into arguments with his manager and his manager couldn't really reprimand him, because if he did, QJ would have just got madder and refused to go to work.

QJ's aunt: When he first started, he was really proud and had a great sense of achievement, that "I found this job all by myself" feeling. He was saying, "I am doing well at the place, and the managers and co-workers treat me very well." He claimed that he was very happy.

The workplace was planning to pay into insurances and pension for him. Upon learning that he had been receiving a low-income subsidy, the workplace told him to give up the subsidy for the insurances and pension. I don't know what my sister was thinking. She was probably worried about whether this job could be long-term, and about QJ losing the low-income subsidy and grocery subsidy from the local government once he got a paying job. She didn't think it was a good deal, so she asked QJ not to continue at the job.

QJ's mother: Yeah, I was thinking that he had to pay for transportation and for meals when he went to work, whereas he could save on meals if he stayed home. But I couldn't get him to listen to me.

QJ's aunt: There was no WeChat back then, only the QQ App. He posted on QQ saying that he wanted to jump from a building. I read it and asked him what was going on and why he was feeling depressed. He said, "I found a decent job but my parents won't let me work there anymore." I asked him whether we could reach his manager. I waited for a while before his manager answered my phone. I introduced myself and told him about little QJ. The manager said, "Today is the last day. His mom came yesterday and said he won't work here anymore, so we already put that into the system." I asked the manager, "What do you think of him now that he has been working for a while?" The answer was positive. I said, "I already asked him if he wants to continue, and he does. So will you keep him?" The manager said, "We will, I will. I will change it in the system and he can continue working here." So he continued. I told the manager that even if little QJ had been paid less than what the restaurant was paying him, I would still have chosen for him to continue if I were his parent, because I would want him to have a higher sense of self-value in society. I would want him to build his confidence and believe that he can make his own money and make his own living.

Q: What does he mostly do in the restaurant?

QJ's mother: Washing dishes and moving things around. He is strong and very tall, even taller than his dad. (See Fig. 1)

QJ's aunt: He is good-looking. He looks like Yao Ming, not as tall of course, but with a similar face structure.

QJ's father: His face is square, like his mom's.

Q: How does QJ commute to work normally?

QJ's aunt: He takes the bus both ways. He rides the free supermarket shuttle bus to work and takes the public bus home since there's no supermarket bus by the time he gets off work. He likes to go to work early, by 1 or $2 \mathrm{~h}$, because he can go to the 


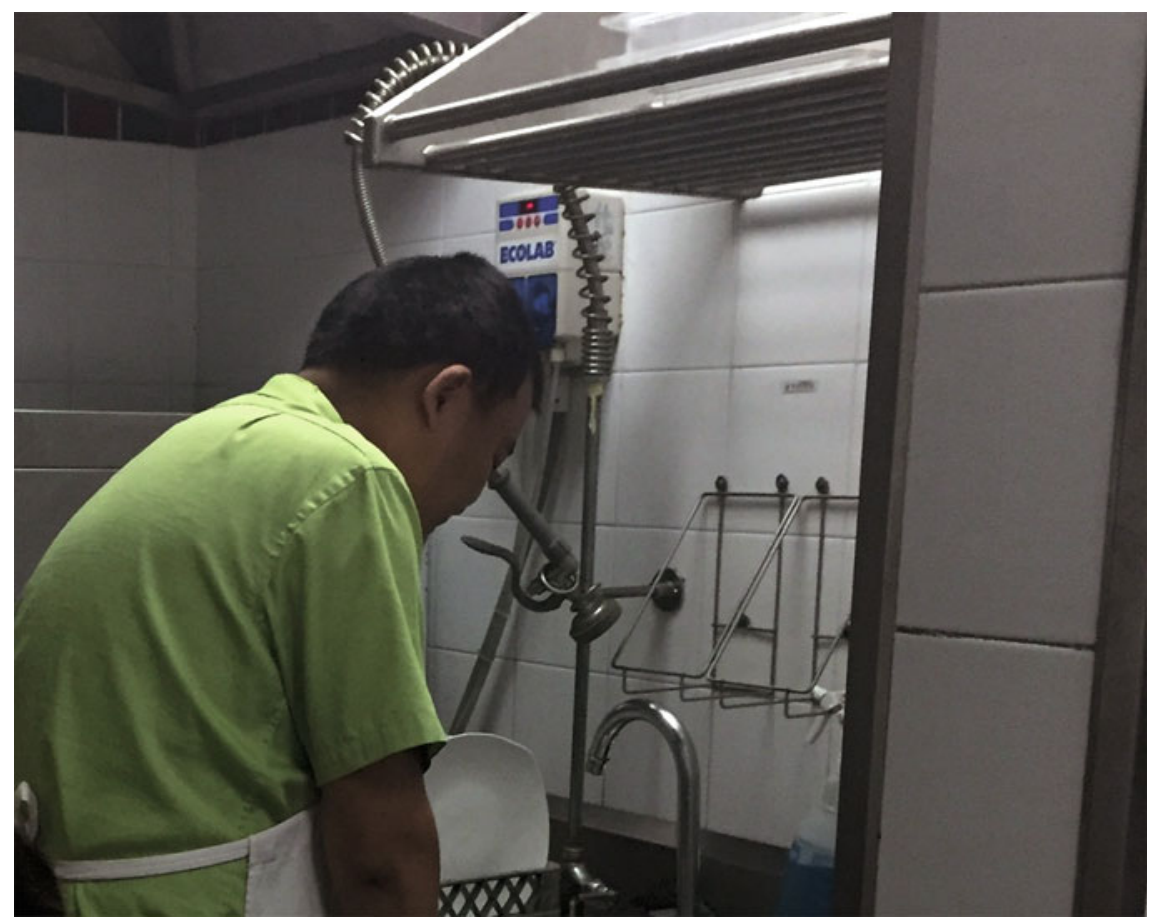

Fig. 1 Mr. QJ at work

Telecommunications Bureau across the street where he can use the free computer and free Wi-Fi. He likes to kill time that way.

He used to come to my house often because the computer at his house wasn't working, so he would come to hang out with my husband and me. Then I told his mom to buy him a new computer. That took some persuading. Now that the computer is working, he doesn't visit me anymore. He said, "I have a computer at home, so I am not going out."

When he came to my place, he wouldn't stay long because he had to go to work the next day. My husband asked him when his workday started and he said, "Either 8 or 9 a.m., I forgot." My husband said, "I get up at 5 a.m. Why are you in a hurry to go back home since you start work at 9 a.m.?" But he insisted on going home because he didn't want to be late for work. He goes to bed very early at night and won't go back to sleep once he wakes up at 2 or 3 a.m. He will just play on the computer till it's time to catch the bus to work.

QJ's mother: He sets the alarm at 7:45 a.m. every day. The cell phone wakes him up and he goes to work after washing his face.

QJ's father: He usually comes home at 9 p.m. after work. I have asked him to limit his computer time to $2 \mathrm{~h}$ if he can. He usually plays on the computer till 2 or 3 a.m., which should have been the best time for sleeping, so I don't like it. Sometimes he 
would play till 4 a.m. before going to bed, and I would tell him, "This isn't right. I want you to sleep the first half of the night rather than play on the computer till midnight. It's not right to be still up after midnight."

Q: Is QJ doing a good job at work?

QJ's mother: He has the physical ability. He will do what he is told to but won't volunteer for anything. He would not have been hired at some other places.

This kid doesn't know how to cook. I cook two meals for him every morning for him to bring to work. Leftovers are not fresh. He doesn't monitor his physical condition but at least he knows to eat on time. So that's the thing about Papa John's. Privately owned factories usually provide at least one free meal, and we wouldn't have expected two free meals anyway. But by the time he comes home at 9:30 p.m., he would already have had two meals at the restaurant. I think Papa John's should provide free meals, with some meat and some vegetables for every meal, what do you think? You can't have all meat or all vegetables.

Q: When do you get up every morning to prepare his meals?

QJ's mother: I don't have to get up too early, since he doesn't go to work so early anymore. I just get up early enough to get the meals ready for him. He can't do it himself; I have to get everything ready for him.

Q: You have a tough job there.

QJ's mother: Not exactly a tough job. He is my own kid, so I have no choice. And I can't keep him home and not working.

Q: Are all of QJ's co-workers without disability or are there others like him?

QJ's mother: Most of them are without disabilities. There are not many who are like him, only two girls actually.

Q: Does he get along better with the two girls or with co-workers without disabilities?

QJ's mother: Neither, because he easily offends people.

Q: Did he ever come home and tell you that he had made good friends?

QJ's mother: No, never.

QJ's father: We have never talked about this.

QJ's aunt: He did talk about it before. People who knew about his condition liked to tease him sometimes, and he would say, "That girl is very nice to me and quite into me." He would often tell me things like that. If some girls without disabilities came to eat at the restaurant and joked with him, he would be over the moon and tell me, "That girl Tingting is tight with me." My husband would then say, "If she is tight with you, you should be the aggressive one and take her out, like to the park or afternoon tea at a coffee shop." But of course, that would have cost money. And he would say, "It will cost a lot of money, so I am not doing it." My husband would then say, "If you ever want to get married, you will have to spend money." And he would say, "What if I spend all my money on her and then she dumps me?"

QJ's mother: He said, "If I got together with someone from outside Shanghai, she might take off in the end with all my money, like what happened to Uncle. So it's a big no-no." He is street smart in that way.

Q: Does QJ eat out or go out for fun with co-workers after work? 
QJ's mother: Not now. At first, they would invite him along to karaoke, but then they stopped. He mentioned that they no longer invited him. I think maybe the coworkers are worried that there would be no public transportation for him to go home after midnight.

QJ's aunt: Another possibility is that he probably didn't know how to pull up the songs, so he would occupy the karaoke console for a long time and people would lose patience. Also, he liked to sing old songs which no one wanted to hear, and he monopolized the machine and kept singing one song after another, so that put people off too.

Q: Which songs does QJ like to sing?

QJ's aunt: Old songs like Paddle in Hand. There's another one but I forgot the name.

Q: How much does QJ make per month now?

QJ's mother: Around 1,500 yuan, or around 1,800 yuan with triple-pay ${ }^{3}$ for overtime.

Q: Has QJ had pay raises since he started working?

QJ's mother: Not often. He started with 800 yuan and makes around 1,500 yuan now.

QJ's aunt: I have a suggestion. He found the Papa John's job himself, and that place hired quite a few people with ID. People with ID usually don't know how to find jobs themselves, but QJ was able to find one on the Internet. I believe that we should help this kid build confidence. Why? He has been working for a long time now but makes so little money. My sister can't get a specific number out of him, and I don't know either. I just have the impression that it is 1,800 yuan. He has worked at Papa John's for 8 or 9 years, if not quite 10 years yet, and his pay is pathetic next to what most people are making.

Q: Who is in charge of QJ's salary now?

QJ's mother: He picks it up himself.

QJ's aunt: It's like that. His mom doesn't know how to operate the bank machine, so he does it himself. I figure that his mom tells him to only withdraw whatever he needs to use every month and to leave the rest in the account. He is very thrifty.

QJ's mother: He takes 400 yuan and gives the rest to me every month. He told me to deposit 10,000 yuan into his savings per year.

QJ's father: Young people need to know how to make money last. He doesn't make much money to begin with. If you don't save when you are young, it will be too late to save when you get old.

Q: Where does he spend this 400 yuan?

QJ's father: Not sure. His mom prepares two meals for him every day. If those are not enough sometimes, he might buy snacks.

QJ's mother: Yeah, he buys snacks.

$\mathrm{Q}$ : What snacks does he like to buy?

\footnotetext{
${ }^{3}$ Triple-pay for OT: Triple pay for working on statutory holidays.
} 
QJ's mother: There are a lot of drinks at Papa John's and he could have taken some but he doesn't. He likes to go out and buy other drinks and just throws the empty bottles under his bed.

QJ: Does he save money himself?

QJ's mother: He doesn't. He uses up the 400 yuan I give him every month. He spends most of it on the transportation card, because he spends 2 yuan every day taking the bus. If I give him more than 400 yuan, he will spend it all. If I give him less than 400 yuan, the same thing happens. When he is out of money, he won't tell you or ask you for more, but he does spend every penny he has with him.

He used to be very serious about this job, but now he wants to quit. He already fought with the shift manager twice and just left the restaurant for that day. But he didn't come home till the time he would normally come home from work, so I had no clue about anything. He told me, "They laid me off and I am not going back." I asked him what was going on and he couldn't really tell me. So I called the manager who said, "It didn't happen like that. We were very busy on October 1 and the lady who helps washing dishes didn't show up, so I asked QJ to wash some more dishes. But he spent several minutes washing just one dish, because I walked around the restaurant and came back to see him still washing the same dish. So I asked what's going on with him and he got mad at that and threw down the dish and stormed out." This manager is a very nice person and told me, "Ask him to come back to work tomorrow." This happened twice, his refusing to go back to work. I told him, "Where are you going to work if you don't go back to this place? You can come home, but you already lost your low-income subsidy. If you don't work, how are you going to feed yourself?" So he had to go back to work, I forced him to go back twice already. I said, "If you run away from work for a third time, they will really lay you off." He said he understood. He still listens.

QJ's aunt: Even with his intellectual disability, he has self-respect, and actually his sense of self-respect is stronger than that of people without disabilities. People without disabilities might consider compromising, but he won't, his only thought is to go forward.

QJ's mother: His co-workers used to treat him as equal, so he was serious about the job. Now people at the workplace just ignore him, so he isn't motivated to work. Because he talks too much, people get mad at him. Maybe what he said offended people, so he was reluctant to continue working there. I asked the manager whether it was because little QJ would say things to offend people and people would get mad and not talk to him. I also asked the manager to make sure that the co-workers are more tolerant towards QJ and don't take him too seriously. The manager said he would do that. He is a really nice person.

QJ's aunt: Sometimes people find him funny and tease him for a laugh. Out there, people make fun of kids like him. Then they lose interest after a while because there's only so much to tease about, so QJ might feel that people are staying away from him.

QJ's mother: When he first started working, he was not assigned the triple-pay OT. Then he asked for it and got it. He said he didn't want to take afternoons off but he doesn't seem happy going to work in afternoons. 
QJ's aunt: One thing little QJ says all the time is, "They laid me off." He would often call us up to say, "Aunt, they laid me off. Uncle, they laid me off." He always says this and not much else.

Q: Were there only two times when he was frustrated at work? On what other occasions, besides when he is down, would he say, "They laid me off"?

QJ's aunt: He always says this whatever the occasion. He says this whenever he sees us and he also says, "So now you can gloat, they laid me off-you must have badmouthed me at the workplace." I don't know where he got this from or whether he had this planted in his mind by someone else. His dad often tells him, "Try your best, otherwise you will be laid off." So this was probably where it all started. When he meets with my husband, he says similar things like, "Now you're happy, they laid me off." When he first said this, my husband was puzzled and found it hilarious, so he said, "Whether you were laid off or not has nothing to do with me. You don't make money for me. I actually hope that you can make money, so why would I be happy if you were laid off?" My husband came back home and mentioned this to me, and I had to tell him that's just what QJ likes to say. He is always mumbling to himself.

Q: Do you talk to the manager often?

QJ's mother: We seldom contact him although we have his phone number.

QJ's aunt: I have his number too.

Q: Have you ever been to the restaurant to see how QJ works?

QJ's mother: We haven't.

QJ's aunt: They don't care. Even though they both stay home all day, they won't bother. My husband and I want to go, but I won't let my husband go because I don't want to be liable should something happen. My husband suggested that we go to the restaurant to eat. He said quite a few times, "Little QJ, we are going to eat at your restaurant-you better give us a bigger pizza!" He was joking, of course, because we couldn't have finished a pizza between the two of us.

Q: How does QJ communicate with his parents?

QJ's aunt: He would consult me on important things, but he hasn't done that for a while.

QJ's father: He needs someone to support him when it counts, and his aunt supports him a lot. He actually tells people that his aunt supports him when he needs support most.

QJ's aunt: He said, “Aunt, thank you. Because of you, I am able to keep my job, otherwise I would have been laid off a long time ago."

Q: Growing up, how well did QJ communicate with his friends?

QJ's aunt: There was hardly any communication with classmates, co-workers, or neighbors. He used to come to my house often, but stopped after he got a computer. My husband asked, "What's going on? He used to come all the time. Now it must be his parents who won't let him come." I said, "That's not it. He has a computer at home now, so he stays home to play on it." My husband likes a full house. Every time little QJ visited, he would ask him whether he had had dinner. Even if he had, my husband would ask him to drink some wine and eat more. 
QJ's mother: A neighbor asked him once, "QJ, how are things at home?" And he replied, "Mind your own business." He asked people to mind their own business, which was offensive.

Q: How do your own kids get along with QJ?

QJ's aunt: They don't hang out and have no contact. If I invite my sister's family over to eat, they don't talk to each other. The only thing QJ says to my daughter is that he is going to be laid off. He doesn't say anything else.

\section{Difficulty in Learning to Take Care of Himself}

Q: When did QJ learn to brush his teeth and dress himself?

QJ's mother: Around ten, or maybe when he was seven or eight.

Q: Does QJ help around the house?

QJ's aunt: No, he doesn't.

QJ's mother: We don't want him to.

QJ's aunt: But you should still have taught him.

QJ's mother: He doesn't do a good job. I asked him to do laundry and told him, "Why don't you do it yourself because once we get old, no one will do it for you." But he messed it up. After he hung up the clothes and left, I took them down and washed them again.

Q: Did you teach him how to do laundry?

QJ's mother: I did, but he still can't do it well.

QJ's father: He really has no clue how to wash the clothes clean.

Q: So does he do his own laundry now or does Mom do it for him?

QJ's mother: I do it for him most of the time. Now that he is working, I do force him to do it himself and I just wash everything again if he messes it up.

QJ's father: Since he goes to work late, I have asked him to do his own laundry. Whether he wastes water doing it is another matter, since it's kind of normal for kids to waste water when doing the laundry. Then his mom will wash again what he has washed. He doesn't do a good job hanging up the laundry either. (Walking to the balcony to show the interviewer) Just like when you put on your clothes, you need to pat down every corner to look sharp. I told him, "When you hang up laundry, make sure where the left side is and where the right side is, and straighten everything out so there will be no wrinkles." He is not a kid anymore, but we have to teach him how to hang up laundry. Such things as hanging up laundry should be no-brainers, right? He is in his thirties and can't even do a good job with laundry. We are both 60 now, and by the time we are in our eighties, he will have to be independent. But he isn't independent now.

Q: Do you take the time to teach QJ common sense things?

QJ's mother: It doesn't work. We would teach him today and he would forget tomorrow, so we have to repeat every day.

QJ's father: When he was young, his mom would plant in the field and I would be helping out when I was not at my own work. I remember that when we were 
planting together, sometimes we would run out of seedlings and other kids would have fetched some for us. But he wouldn't because he had no sense. Even as far back as then, it was already apparent that there was something missing with him.

$\mathrm{Q}$ : Does he clean his own room?

QJ's father: Never. Don't even get me started on that. He never cleans his room and when I clean it for him, I always find empty bottles and other trash under his bed. He would drink and eat dry noodles, for example, in his room and never bring out the trash to throw away or put the trash in the trash can. His room is dirtier than public places. In the morning, he just throws back the comforter when he gets up and leaves for work.

QJ's mother: He does clean up but doesn't do it well.

QJ's aunt: When he sweeps the floor, he doesn't have a pattern. He does it really random, so how can he do a good job?

QJ's mother: He doesn't know how to organize. Before he leaves for work every day, I would straighten his clothes for him because he won't bother if the clothes are sticking out in all directions. He has Monday off, so I bet the manager or someone else has told him, "QJ, your work clothes are too dirty, can you take them home to wash them on your day off?" That's why he brings them back. The work clothes are washed at least once a week. If no one reminded him, he would not have brought them back. If the clothes had been left at the restaurant, he would not have washed them himself.

\section{Multiple Interests Including Travel and Photography}

Q: When QJ was at elementary school, did you take him out on weekends?

QJ's mother: His aunt took him out.

QJ's aunt: I always took him out on my days off.

QJ's father: We seldom went out on weekends because we were so busy. The first time was when his sister wasn't in school yet. His mom proposed it since she had time and I had time. The kids always had time anyway, so it was fun to go out as a family. The farthest we traveled was to Chuansha.

Q: So you took QJ out a total of two times?

QJ's mother: Yes, a total of two times. The first time was when his sister wasn't in school yet and little QJ had just been born. The second time was when little QJ was seven or eight and already in school.

QJ's aunt: They went out two times and his mom fell into the river on the second trip, so they just stopped going anywhere.

QJ's father: Had an accident on our second trip. There was a stone bridge on our way back home and QJ's mom fell off the bridge into the middle of the river. She would have drowned if she had stayed long in the river, so I jumped in after her. Luckily, I knew someone living in that area, so I told him, "It was supposed to be a happy outing for the entire family, but my wife fell into the river. Can you please 
help us?" So he lent us some clothes. My wife washed them and hung them to dry and I returned them the next day. She is very accident-prone outside the house.

Q: Does QJ go out for fun on weekends now?

QJ's mother: Now, if he doesn't have to go to work, he will get up in the morning, wash his clothes, and go out for some fun.

QJ's aunt: Little QJ will take pictures of this and that on his phone and post the pictures on QQ, captioning them Childhood Memories or memories of other times. I asked him why he always lives in memories. It's not good to do that. We should look forward, not backward.

Q: On weekends when he goes out for fun, does he come back for lunch or eat out?

QJ's mother: Sometimes he won't come home till night, sometimes he comes home for lunch.

QJ's aunt: Actually, when he was young (to QJ's mother) (takes out the pictures), little QJ was very cute.

(QJ's father showed the interviewer pictures of his grandson on the coffee table and family pictures at the airport. QJ's mother went to another room to fetch more pictures.)

QJ's mother (with lots of QJ's pictures): He had these printed.

QJ's aunt: He likes to take pictures.

QJ's father: He takes really good pictures; I am not kidding.

Q: How old was he when he started showing an interest in photography?

QJ's aunt: When he was really young. (Pointing to a mole on QJ's face) He doesn't have this mole now. He asked his parents to take him to have it zapped.

$\mathrm{Q}$ : Was he going out for fun by himself in these pictures?

QJ's aunt: Yes, by himself.

Q: Then who took the pictures for him?

QJ's aunt: He asked passersby to take pictures of him.

Q: Does QJ like going out for fun by himself and traveling?

QJ's aunt: He isn't into travel. He just bikes around the neighborhood. And he knows how to take the bus, which is why I don't think he is slow. He told me, "Aunt, when you take the bus, tickets for lines that are numbered start at 2 yuan and lines with Chinese names such as Shilao Line start at 1 yuan. So what do you do? You get on Shilao Line and pay 1 yuan, then you get off and switch to a line that is numbered and pay another 1 yuan, and that will save you money." So he rides the bus around for only 1 yuan.

Q: QJ's aunt said that he really likes to play on the computer. Who taught him how to get on the Internet?

QJ's father: Neither of us two know what to do. He saw that everyone had a computer, so he wanted one too.

QJ's aunt: I figure that his sister taught him, because computers became popular in 2009 , or maybe 2010 or 2012, just one of those years. My husband sells accessories for home appliances and bought a used computer for 400 yuan. Then my sister said that her son wanted it, so we gave it to him and he started using it. I don't remember whether I taught him or someone else did, it has been so long. 
QJ's mother: He took classes, spent 100 yuan on learning how to use the computer.

Q: How old was he when you sent him to learn how to use the computer?

QJ's mother: He was in his twenties.

Q: Is he still using the original computer?

QJ's aunt: No, he got a new one.

Q: Who bought the new one for him?

QJ's mother: His aunt bought it online.

QJ's aunt: I bought it on Taobao for 1,380 yuan, or maybe 1,480 yuan. Over 1,000 yuan anyway. I bargained for a price reduction.

Q: Did he pay for it himself?

QJ's aunt: His parents paid for it. Here's the thing, no one else can access his computer. He has set a password for the computer, and for his cell phone too, so no one can access his cell phone either.

QJ's father: What's happening now is that he stays up late to play on the computer. The two of us would be sleeping and then get up at 1 or 2 a.m. to use the bathroom, and he would still be on the computer. Not sleeping at that hour isn't right.

QJ's mother: When he has to work, he gets up late. On his days off, he will get up very early and go out after doing his laundry. If I tell him not to go out, he will just ignore me.

Q: QJ's aunt said that he likes to play on the computer. What does he usually do on the Internet?

QJ's aunt: I don't know what he does on the computer, but if you ask him to write something, he won't know how. One time when his dad needed to write a work report, I said, "Little QJ, you know how to get around on the computer. Can you look up online how to write work reports?" But he didn't know how to do it. So I ended up writing the work report for his dad. If I ask him to check something online, he won't know how to do it. I taught him to just enter the keywords for the results to show. He didn't even know that-it's amazing how he managed to find the job.

He would play on QQ sometimes, but he types really slow and doesn't know how to chat. Some people would get mad at him for typing so slow. At first, he applied for several QQ accounts and kept them all active and added a lot of friends. But once a girl reached out to him to chat, he didn't know how to chat. Several times when he came to my house, I would pretend to be him and chat with his QQ friends. As for meeting in person, he asked, "What if they want to meet?" And I told him I would go with him to meet them. Now I don't know how he chats with other people.

You need a password to log in QQ, so he would input his password while facing you to keep it secret from you. He has 16,411 pictures and 3,017 posts in his QQ and the last post was from 2014. He always posts some strange numbers and letters which make little sense. He also forwards pictures from my QQ to save in his own QQ album.

Q: Does he have a lot of friends on QQ?

QJ's mother: Nope. He lied to people by telling them that his mom worked as a teacher and his dad worked at an equally high-level job. Once people found out that he was lying, they just stayed away. 
QJ's aunt: He has no friends, no friends he can talk to. Just people he will chat a bit with one day and never talk to again.

Q: He must be good with the cell phone, right?

QJ's father: He is good with the cell phone, better than we are. We don't know what to do with the cell phone.

QJ's aunt: He is good with the cell phone and I added him on QQ, actually my whole family added him on QQ. But he keeps bothering us, so we didn't add him on WeChat. My sisters all ignore him on QQ and WeChat, they either deleted him or blocked him. My daughter said he bothered her at work so she blocked him. He would call for no reason with only one thing to say, "I have been laid off, now you can gloat. You must have badmouthed me."

Q: Does he have his own cell phone?

QJ's aunt: He does. Maybe his mom bought it for him.

QJ's mother: He had a phone which my younger sister gave him. It's a nice one with a big screen. But he wanted an iPhone. I told him, "iPhones cost too much and it doesn't make sense to buy one." He said if people said bad things about his phone, he wouldn't keep it. So he took the phone to work and someone said, "This is a cool phone, QJ. Where did you get it?" He said his aunt gave it to him. So he kept that phone and really liked it. Then he bought a used iPhone which is pretty decent—worth 2,000 or 3,000 yuan.

Q: Who is using the iPhone now?

QJ's aunt: His mom doesn't know how, so he uses it himself.

QJ's mother: He uses it and usually leaves it at home. He might have brought it to work today.

\section{Hoping to Have a Wife and Kids}

Q: You mentioned QJ's uncle before. Does this uncle have the same condition as QJ?

QJ's aunt: No, his uncle can live independently. After he got married, the wife ran away. The two of them were just so unsuited-even their lifestyles were different, so she left and he has been on his own with no kids.

My feeling is that when little QJ's father communicates with him at home, what he says isn't to the point. He would say things like, "Without your disability, you would have been married with everything." He shouldn't have said that. Little QJ is already at this age, and of course he wants a wife and everything. He would be looking at a picture of a couple with a child in the supermarket and say to me, "Aunt, they are married with a son, my younger cousins are all married, but I'm not." So that's weighing on his mind.

Q: When did your family start matchmaking for QJ?

QJ's aunt: When he was 25 or 26 . He would keep saying that everyone had a girlfriend. My husband always told him he would find someone for him and he would ask, "Uncle, how do you date?" And my husband would joke with him, "Get the money ready, ask your parents to get the money ready." I would say, "You don't 
have to tell him that. Once he has a girlfriend to bring home, his parents will definitely have the money ready, because what they have been doing their entire life is for this son." Little QJ asked how much money he would need and my husband just threw a number out there to scare him.

Q: How many times did you try matchmaking?

QJ's father: Two or three times.

Q: Was there anyone who lasted?

QJ's aunt: No. It never went past the first date, because he doesn't communicate, even though he wants to from the bottom of his heart.

Q: Did his parents find the dates for him?

QJ's mother: Someone else did.

QJ's aunt: When he first started working, people liked his looks, and one girl asked him if he wanted to date her younger sister. So he met with this girl who worked at Pudong Airport. On the bus, the girl sat next to him and put her head on his shoulder. Other guys would have reacted to this by patting her or some other gesture, but he was too scared to do anything. His mom heard about this and asked him to give the girl a little pushcart the next day. But then the girl just stopped dating him. Now he is always saying, "That girl would have been a good match, but you badmouthed me to her and ruined it." He accused us of telling the girl that he has ID and of saying bad things about him, which was why the girl stopped seeing him. That was nonsense because we knew nothing about anything.

QJ's mother: He did tell me about this, when he was 25 or 26 . I told him to bring the girl home but he didn't.

Q: How did QJ's aunt teach him how to date?

QJ's aunt: I said, “Let's start with role playing. I will pretend to be your girlfriend and you will be yourself. But you will have to talk first by asking me how old I am." He said, "You ask me my age." I said, "No, you ask me how old I am." He said, "How old are you?" Then I said, "Now you can ask me my name." So I asked him to go on with the questions and to tell the girl about his own job and family. But he started losing focus if I went on and on.

When I was teaching him this, my other younger sister who also lives in Shanghai was present and she said, "Sometimes you don't want to say too much because it could have the opposite effect." After she said this, he decided not to utter a single word. But if he doesn't break the ice by asking questions, girls won't take the initiative.

Last time my younger sister introduced a girl to him. She seemed to have some disabilities, something wrong with her eye. She was good around the house and had a job too. A decent girl who had been single for a long time and was 2 or 3 years older than him. She sounded like a good choice. I wanted to go with him to meet her that day, because he wouldn't know how to communicate and I would have to communicate for him. The two of them would have to live under the same roof if it ever came to that. If there was a third person around, he wouldn't say anything. But if it was just the two of them, he would have the chance to get to know her and he would definitely find things to say. So they met for the first time, and since I didn't go with him, I had no idea what he said or didn't say. My younger sister told him not to talk too much. So the two of them spent some time alone in a room and neither 
of them said anything. How would that work? The girl's older brother said, "They don't have anything to say to each other, how can they form a family?" So the girl turned him down. I had a good feeling about that girl. If she had married into the family, she could be taking good care of his parents. Too bad she is blind in one eye.

QJ's mother: There's nothing wrong with her eye. She has a scar on her face and is actually pretty.

QJ's aunt: Right, she is pretty, and probably had a trauma wound. If I had gone with him that time, he might have succeeded with her.

QJ's mother: He wasn't interested in that girl, he said, "Her face is scary to look at. I can't possibly be seen with her."

QJ's aunt: The one we were talking about was introduced by my younger sister. There was another one that I went with little QJ's mom to check out.

QJ's mother: We checked out that girl twice and it wouldn't work. On the date, there were two matchmakers, and two from the girl's side, which made for five including little QJ. Her parents came too and followed in the back. In front of all those people, that girl talked non-stop to her parents. It's not the right way to behave on a date. She also told little QJ, "You will give me your money in the future." Rumor had it that she spent all the money she made. Then someone else introduced this same girl to him. She asked him out and he refused to go, saying, "I don't make enough for her to spend."

\section{Insurance Purchase Out of Worry}

Q: When did he get his disability certificate?

QJ's mother: When he was 17 or 18 , close to 20 . We took him for an assessment at a hospital in Pudong and the results showed that he has severe disability.

Q: Why did you choose that particular time for the assessment?

QJ's mother: Because at the time of the government-mandated relocation, neither my daughter nor my son had turned 16. The team leader told me, "Once your son turns 16, go get him a disability certificate." Because once a kid with a disability certificate turns 16, he can receive subsidies from the local government.

Q: Exactly what subsidies did he start receiving once he got the disability certificate?

QJ's mother: He received a subsidy of 200 to 300 yuan per month for the unemployed and severely disabled. There's also a grocery subsidy for people with disability certificates. You got 12 coupons each year and you could exchange 1 coupon every month for either rice or cooking oil but not both, and 1 coupon got you $20 \mathrm{lb}$ of rice. So we went to get the rice every month and there was always some leftover from the month before, and we got enough to cover his consumption. But that subsidy stopped once he started working.

The disability certificate also qualified him for 200 or 300 yuan per month in disability subsidy. But it stopped too, like the grocery subsidy, once little QJ started the Papa John's job. There's nothing now. 
The disability certificate was kept on file at the Civil Affairs Bureau which distributed the subsidies. Once little QJ got the job, the bureau returned the disability certificate to us and stopped all subsidies.

Q: Were there any other subsidies besides the grocery coupons and cash?

QJ's mother: Not really. One time he received a comforter for Chinese New Year, but things like that are very random.

Q: Does the current workplace pay into social insurances for QJ?

QJ's father: We're not sure.

QJ's mother: It should be doing that. When he was receiving low-income subsidies, the Civil Affairs Bureau paid into his insurances. Now the workplace does it.

$\mathrm{Q}$ : When QJ was growing up, what care do you think he received from the society besides the low-income subsidies?

QJ' mother: Now there's nothing. Before he started working, there was the grocery subsidy, but it stopped after he got the job. Before he joined Papa John's, he received free things every year or the Community Affairs Committee would give him 100 or 200 yuan for Chinese New Year. Once he started working at Papa John's, everything stopped. Like this year, he only got two towels, because he sang at an activity hosted by the community for people with disabilities and was awarded the towels.

Now he receives 100 yuan per month. The Community Affairs Committee asked me to get a bankcard and I asked the bank if I could use an existing one and the answer was "Yes." So I asked for the money to be deposited into the existing card. I don't really know what this monthly 100 yuan is for, but it's definitely from the Civil Affairs Bureau. He has been receiving it for less than 6 months.

QJ's aunt: Families like theirs with a childlike QJ must feel depressed and unhappy, so society should show them more care. If only there was an organization that would allow them and their kids to live there after they get old, they would be very happy living there despite the ID of their kids.

QJ's father: Just like QJ's aunt mentioned, I wish there was an organization to connect us with families like ours.

QJ's aunt: Luckily, they have a daughter too. If they had only one child, this child would be isolated from society and not be able to get a girlfriend. Once the parents get old and need someone to take care of them, they wouldn't be able to count on kids like QJ and wouldn't have anyone to take care of them. I think society or the government should do something for these families, like setting up an organization for them to be with each other. The parents can have fun talking to other parents, and families can have a chance to communicate and interact.

QJ's father: I couldn't agree more. We are already 60 and should have passed down everything to the kids. But we can't pass anything down to him, and even though I have a daughter too...

QJ's aunt: Their daughter has her own kid and is busy with her own family. She can't be involved all the time.

Q: Do you know anything about the organization Sunshine Home? ${ }^{4}$

\footnotetext{
${ }^{4}$ Sunshine Homes: One of the practical projects of Shanghai Municipal Government in 2005. These are training institutions set up to assist and train people with ID aged 16-35 years. The main tasks
} 
QJ's aunt: I do. I read about it on the Internet before. It's a place for kids and parents to be together and to communicate, and it sounds fun. As a matter of fact, society should give kids like QJ and their families more warmth and not discriminate against them.

All of my sisters and other relatives hope that QJ would have a better life, and we would worry less if QJ's parents had some place to go where they can be taken care of when they get old. In some other families, the siblings might compete against each other and not want the others to have a better life than they do. But with us, I will be happy when you are doing well, and if you are not doing well, I will find money to help you even if I am broke myself. So the society should show them more love and care, in all aspects. They should receive equal treatment in life, at work and in pay.

QJ's current workplace seems to think that they have already done QJ a big favor by hiring him and paying him despite his disability, so he should have no reason to complain. But they enjoy tax exemption for hiring people with disabilities. ${ }^{5} \mathrm{QJ}$ has been working there for almost 10 years and doesn't have any sense of achievement. Now he only looks forward to Chinese New Year because he can get paid more then. He is always saying he wants to have the triple-pay OT and whenever he gets to do it, he's over the moon and won't stop telling me about it.

Q: What plans do you have for QJ's future?

QJ's mother: If we have the chance, we will find him a wife. If there's no chance, it's better for him not to have a wife than having a bad wife. We don't want him to end up like his uncle whose wife took off with his money and who ended up with nothing. We are at the age where we can't afford for that to happen to us or to him. We have to put some money aside for him to use when he gets old, right? If we can't find a good girl for him, he will have to settle for being single. He did ask me, "My older sister has a son. What am I going to do in the future?" I told him, "Don't worry, even though your older sister has a son and you don't. You will definitely live better than we do. We don't have enough pension, so we might go to live in a nursing home. But by the time you get old, you will have enough pension. If your sister and nephew will support you, we will give her this apartment. If not, we will leave this apartment to the government or to the nursing home and you can continue living in it. I also bought you insurance and you can start receiving pension once you turn 60. You will definitely live more comfortably than we do." And he said, "It sounds good." He has street smarts.

include educational training, rehabilitation training, Special Olympics, and simple physical works, etc. The purposes are to help people with ID improve self-care ability and social ability, and to enhance their inclusion into society. Most trainees are people with ID of medium to severe level. The opening hours are normally between 9:00 and 15:00 on workdays. Currently there are 241 Sunshine Homes in Shanghai, covering all communities, villages, and towns in the whole Shanghai area. There are also similar institutions in other places in China, though their names might be slightly different.

${ }^{5}$ Chinese Government has issued tax-exemption policies for hiring people with disabilities, applicable solely to welfare enterprises; e.g., exemption of land usage tax. Non-welfare enterprises cannot enjoy these tax exemptions, but are entitled to a reduction of corporate income tax. Papa John's is a non-welfare enterprise. 
Q: So you bought QJ insurance? Can you be more specific?

QJ's mother: I bought it from Ping An Insurance Company for him to receive more pension in the future. We paid for 6 years for him at 3,000 yuan per year. It started the year we moved into this apartment, which was 18 or 19 years ago. We did make two withdrawals already, when he was 18 and 20, at a little over 1,000 yuan each time. The rest will stay in the account till he retires at 60 and he will probably withdraw once a year. Once he retires and has to rely on his sister, we hope that she won't have too heavy a financial burden. So I just wanted to buy more insurance now for him to have more pension when he gets old.

QJ's father: My idea is that with a child like QJ, we will still be burdened even after we get old. Daughters are married off to help another family continue the bloodline. Sons are your own who are to inherit from you. I am 60 already and can't expect to live another 60 years. I don't expect much from him except that he keeps a stable job. Parents are supposed to be supported by the son, but we can't expect him to support us. He can't even take care of his own life, so the best we can hope for is not to have to support him.

I am lucky that I have a daughter too. Things would have been really bad without this daughter, because who is going to take over this family then? We have had a happy first half of our lives. As for the second half, my biggest worry is that QJ cannot live on his own. I told him to be brave, meaning that he shouldn't rely on parents. At his age, I was already working and fixing breakfast for myself. If I had to leave the family for a couple of months to work, I would bring 50 or 60 yuan for food. I gave QJ a comparison. My sister's son has been saving all his gift money his relatives gave him for Chinese New Year ever since he was young. That guy really knows how to save. I told QJ, "No matter how high your pay is, if you don't save, it won't work."

My son is already in his thirties and overdue for marriage. Despite his disability, I wish for a daughter-in-law from the bottom of my heart so that he can carry on the bloodline. If I can't have a biological grandkid from him, even an adopted one will serve the purpose. Everyone seems to have a good family life, but what about us? We don't feel good about it. I am already 60, like the setting sun, but I see no hope. Parents get old and kids are born, like a rolling wheel. How can I not be anxious seeing him the way he is?

\section{Interview with QJ's Co-Worker (I)}

Interviewee: Ms. A

Interviewer and writer: Xinhui Chen

Interview date: December 2, 2016

Interview place: Restaurant where QJ works

Q: What do you think of QJ? 
Ms. A: I feel that he is very well behaved. He is willing to work, but is just too well behaved and doesn't say much.

Q: Is there any difference between him and other co-workers?

Ms. A: The only difference is that sometimes he would put a dish away that is not totally clean. But he is willing to work. When it was time to take annual leave last time, he said, "Are they asking me to take annual leave? I won't get paid if I take the leave." He works hard. He washes dishes when there are dishes to be washed and just sits in the back when there's nothing to be washed. That's why I said that he is too straight laced.

Q: Do you interact with him often?

Ms. A: Not really because I work in the dining area. Sometimes I would ask him to move things if they are too heavy for me-he is willing to do whatever you ask him because he has the physical strength.

\section{Interview with QJ's Co-Worker (II)}

Interviewee: Mr. B

Interviewer and writer: Xinhui Chen

Interview date: December 2, 2016

Interview place: Restaurant where QJ works

Q: Do you think QJ does his job well?

Mr. B: He does.

Q: How would you describe him?

Mr. B: He is serious and earnest about his job.

$\mathrm{Q}$ : Is there any difference between him and other co-workers?

Mr. B: There is, since he is an employee being cared for ${ }^{6}$ after all. But he does his job well, does not make mistakes and is very reliable.

Q: Do you interact with him a lot?

Mr. B: Not a lot.

Q: Does he approach you to chat?

Mr. B: No. He just washes dishes and rests over there or sleeps when he is done. And he goes home as soon as he clocks out.

Q: Do you hang out with him after work?

Mr. B: No. He goes straight home after work.

\footnotetext{
${ }^{6}$ In Shanghai Papa John's, the employees with disabilities are referred to as "employees being cared for.” (爱心员工) Words such as “handicapped" are not used.
} 


\section{Interview with QJ's Co-Worker (III)}

Interviewee: $\mathrm{Mr}$. C

Interviewer and writer: Xinhui Chen

Interview date: December 2, 2016

Interview place: Restaurant where QJ works

Q: What do you think of QJ?

Mr. C: He is nice.

Q: What about his work?

Mr. C: As for his work, he washes dishes every day. We only want him to finish what he is supposed to do and don't really expect anything extra from him. When he was first hired, there was job training. He couldn't boil noodles or do anything except for washing dishes. I used to ask him to watch the noodles I was boiling and to stir when necessary. He was doing okay at the beginning, but then the noodles got all stuck together, so I stopped asking him to help. All he needs is to do what he is supposed to do. Look at him, sometimes I wonder if he knows where he is. We don't usually have a lot of customers and he usually has to wash only two or three baskets of dishes. Even when we're busy, he isn't. So he would sit there sometimes and run off other times to no one knows where.

Q: Do you have any feelings about working together with employees being cared for?

Mr. C: I don't have any feelings about that.

$\mathrm{Q}$ : Is there frequent interaction?

Mr. C: No, because I work part time and there's hardly any chance for interaction.

\section{Interview with QJ's Co-Worker (IV)}

Interviewee: Ms. D

Interviewer and writer: Xinhui Chen

Interview date: December 2, 2016

Interview place: Restaurant where QJ works

$\mathrm{Q}$ : Did you join the restaurant at the same time as QJ?

Ms. D: QJ joined 1 month before I did.

$\mathrm{Q}$ : What was your first impression of QJ?

Ms. D: He is a well-behaved person and can get things done. If you ask him to do something, he obliges. His mind is outdated sometimes. He is very careful about his belongings, like his cell phone, and always handles them gingerly. Overall, he is a nice person.

Q: What about his work?

Ms. D: He does a good job. He obliges if you ask him to do something. He stays in the dish-washing room to wash dishes and only comes out to use the restroom when he has nothing to wash. 
Q: Does he talk to you?

Ms. D: We used to be close. When we first joined, he would come out to the dining area to help, like taking orders. Now he seems to have withdrawn into himself and talks less. Maybe he doesn't feel free. We really used to be close which is better than the way things are now.

Q: Why do you think he has withdrawn into himself?

Ms. D: Every time he attended a wedding, he would come back and say, "He is younger than I am and already a dad. I'm not even married." So that could be weighing on his mind. Also, maybe someone said something out of line about him and he didn't feel good about it. I feel that sometimes we can't do without QJ around here, because we are always looking for him and asking, "QJ, please come here and help with this."

Q: In what other ways has QJ changed after all these years?

Ms. D: He has withdrawn into himself and talks less now. Sometimes he listens to songs. He likes Little Apple and would just sit there by himself listening to it.

$\mathrm{Q}$ : His mom said that he used to go out for karaoke with co-workers, is that right?

Ms. D: Right. The previous managers went with us at night for karaoke.

Q: Why did it stop?

Ms. D: We invited him once and he seemed to have made plans. The co-workers seldom do things together after work anyway. He gets off after 10 p.m. every day. Bus No. 991 used to run till after 11 p.m. but now it doesn't run after 9:45 p.m., so he doesn't do anything with us anymore because if he goes home too late, there's no bus.

Q: How does QJ get along with his co-workers?

Ms. D: He gets along fine on the whole.

Q: Does he talk to you when he is down?

Ms. D: No, he doesn't talk to anyone. Sometimes I would say to him, "QJ, thank you." And he would say, "No problem, we are co-workers." Now, maybe I get a little irritable sometimes and I would nag at him if I see something I don't like about him. He does have one shortcoming, that is, he doesn't shower often, so there's this smell about him. Every time I nag at him, it's about that. I would say, "QJ, you do smell and need a shower."

Q: How does he react when you say that to him?

Ms. D: I would say, "QJ, you need to shower and keep yourself clean. That's how you find a girlfriend and get a wife." He said yesterday, "I can never get myself a wife." At the end of the day, that's really the main reason he is unhappy. He also said, "I am going to work at the airport." I don't know why he would say that, so I teased him, "If you get a job at the airport, take me with you." QJ is actually pretty cute sometimes and very kind-hearted.

Q: Have you ever had any argument with QJ?

Ms. D: No. He doesn't fight with co-workers in the store, he never fights with anyone. He is actually very kind-hearted.

Q: Does he volunteer to help you?

Ms. D: He did, but he seldom does it now. He used to come to the dining area to greet the guests, bring them menus and take their orders. Now he doesn't come to 
the dining area. He seems to have low self-esteem, and just slouches there when he has no dishes to wash. He might be staying up late every night. He is very smart in some ways. Since he doesn't want to spend the money taking public transportation in the morning, he takes the free Carrefour shuttle bus at 8:30 a.m., gets to Carrefour at 9 a.m. and hangs out there till 10:45 a.m. which is when he will get to the store. Sometimes I would tell him, "QJ, why don't you catch some sleep? You can come early to wash the dishes afterwards."

Q: Do you feel that he is in a good mental state recently?

Ms. D: Yes, he is.

Q: What about his work...

Ms. D: He works hard. Like with the dishes, he is the one washing them on Saturday and Sunday.

Q: How many days does he work per week?

Ms. D: Six days, and he takes Mondays off. If there's something going on at home, his mom would call the manager to ask for time off. He took last Wednesday or Thursday off because of a family gathering.

Q: You said that he used to come to the dining area to help, right?

Ms. D: He hasn't done that for 2 or 3 years. The previous managers were super nice to him and cared a lot about him.

Q: When did this change start?

Ms. D: I can't pinpoint it. It might have something to do with the ladies who washed dishes. Those who were doing it before all left. They were very nice to him. They never got mad at him or nagged him. I overheard a previous manager saying, "Don't ask QJ to wash dishes, he is not here to wash dishes. I want him to do something else." He was really nice to QJ. So QJ was very outgoing back then. We used to have a co-worker in the dining area who was always teasing QJ and joking with him.

Q: When you communicate with him, do you feel any difference between him and other co-workers?

Ms. D: There is a difference. Sometimes he just doesn't get what you are trying to tell him.

Q: I heard from his aunt that he likes to say repeatedly, "I am getting laid off."

Ms. D: He did say that, and our previous manager told him, "We won't lay you off because we don't have the right to do so." It's all in his own mind.

Q: The manager said that QJ lives in his own small world. What do you think?

Ms. D: Right, he doesn't talk or chat with anyone. During break, he just listens to songs on his cell phone instead of talking to anyone, just like that.

Q: But if you approach him to talk to him, he...

Ms. D: He will respond.

Q: I heard that QJ was unhappy about something at work and just took off. Do you know what happened?

Ms. D: He threw a tantrum and was sulking, so the manager said, "Why don't you go home?" And he did go home. After maybe a week, his mom called, and he came back to work. The manager communicated with his mom. He does have a temper sometimes and is very stubborn. 
Q: After he came back to work, did he ever talk about this with you?

Ms. D: No, he won't approach us to talk, he won't take the initiative.

Q: Will he respond if you ask him, "Why are you unhappy?"

Ms. D: He will say, "Nothing, nothing." He just won't talk.

Q: When you first met him, did you feel any difference between him and other co-workers?

Ms. D: Yeah, I did feel some difference. I could see it. Like T, another employee being cared for that we have here. She is a little different, in the way she talks and the things she says.

Q: What did he do when he first started working here?

Ms. D: Before, he would clean the tables and move things around in the dining area, while in the kitchen, he would fold boxes, carry dishes around, mop the floor, and clean up the area. Now he is basically the only one washing the dishes.

\section{Interview with QJ's Co-Worker (V)}

\section{Interviewee: Mr. E}

Interviewer and writer: Xinhui Chen

Interview date: December 2, 2016

Interview place: Restaurant where QJ works

Q: Can you talk about your impression of QJ?

Mr. E: Overall, he is a mild and honest guy. The good thing about him is that he does whatever is asked of him most of the time and does a good job. But he does have some shortcomings, because he is an employee being cared for after all. So we need to be more loving and tolerant towards him in a lot of things. But if we get busy, we might forget about him during certain periods of time or when it comes to certain things. So we might not have been taking the best care of him. He is an introvert and keeps many things to himself. We have to approach him to ask him, and he isn't very good at communicating.

Q: Do you feel any difference between him and other co-workers?

Mr. E: The difference is pretty significant. If he had been assigned any of the other jobs we have around here, it would not have been easy for him. It would have been not only frustrating for him, but also demanding for co-workers around him because he wouldn't have been able to keep up the pace. So it's not easy to really treat him the same as everyone else.

$\mathrm{Q}:$ When did you start working here?

Mr. E: I have been here for more than 2 years. It's my third year here.

Q: What did you think of QJ when you first got to know him?

Mr. E: He is an introvert and a man of few words. He is lost in his own small world and obsessed with the past, always mumbling to himself about what he was doing in 2004 or how he was in 2005. As far as I know, his family isn't doing the best job taking care of him, because I talked to his mom on the phone several times. His 
mom is very earthy too and doesn't know how to take care of him in many aspects, which has led to his being dissocial now.

Q: How does he interact with you and everyone else?

Mr. E: There's hardly any interaction. QJ has been with this store since it first opened, and I don't know what the previous managers thought of him. Personally, I feel that he seldom interacts with us. We have to take the initiative to show him that we care, like we will be eating something good and remember to share with him. He is like a kid who hides his good things. We can't treat him as an adult. He is more like a kid who isn't even ten.

Q: I heard from his mom that he ran away and skipped work a couple of times. What happened?

Mr. E: I was here during one of those two times. He probably had been traumatized at home. He's already in his thirties, and some of the family relatives are always laughing at him, saying, "How come you are still single when you are already getting old?" Most of his peers already have kids of certain ages, which reflects badly on him and he gets depressed at work. One time I asked him, "QJ, you have not been looking happy lately." And he just broke down and said, while crying, "I want to be a dad, I want to be a dad. Everyone in my family laughs at me for still not being married." So I had to say, "I really can't help you with that. You'd better have a good talk with your family." After a while, something just snapped. It was around the time the golden-color 100-yuan bill was issued, and he held up one of those bills and said, "Golden bill, golden bill, no one likes us, so it's just you and me together." If you don't know him, he can be a little scary sometimes.

Q: Was it his mom who contacted you afterwards?

Mr. E: I reached out to his mom and told her the things that were happening at work. His mom doesn't care much about his work. If we don't contact her, she seldom has questions for us and doesn't even visit the store.

Q: Are there any co-workers he is close to?

Mr. E: Because he doesn't communicate with anyone, there's no one he is really close to. But, at the same time, there's no one he can't get along with. Everyone knows his condition. He has no conflict with any co-worker but has not bonded with anyone either. He just comes to work silently, and if we ask him, he will move things around for us diligently. If you tell him, "QJ, please do this", he will do it, but he won't volunteer for anything.

Q: Is QJ the only employee being cared for at this store?

Mr. E: There's another one, a girl whose disability isn't as severe as his.

Q: How do the two of them get along?

Mr. E: They are not exactly tight, because of the way QJ is. He doesn't want to talk, and a lot of times you will have to get him to talk. He will frown at you, and all his emotions are written on his face for you to read.

Q: Has QJ ever done anything that really impressed you?

Mr. E: He does very ordinary work every day, so there's nothing really impressive. All I can think of now is where he could have improved at work. I can hardly see any highlights about his work. If he were a person without any disability, he probably 
wouldn't have been able to stay at the store. Because of his condition, we have been very patient with him. On the whole, there's no highlight about his work.

Q: Have you seen any changes in him since you joined this store?

Mr. E: He is even less social than before. When I first joined, he wasn't as bad. Now he is basically living in self-imposed isolation with his own self being the center.

I feel that he goes out of his way to be respectful, in other words, he listens well to those above him. He is particularly afraid of messing something up and would rather just not do it at all. Sometimes he would make a minor mistake which we could easily correct with a little extra time, but he would apologize profusely. Even after he was told that everything was okay, he would still sulk for a long time. Maybe he has low self-esteem.

His family is very stingy with him, giving him only several yuan for his allowance every day. He spends only 2 yuan on his daily commute. There's a free shuttle bus from his house to this area, so he takes that bus at 8:30 every morning. Since he gets here really early, he will hang out at the supermarket and not come to the store till it's time to work. Sometimes he would just stand next to the traffic lights, in a daze and not exactly doing anything. When I see him sometimes, I'll invite him to come to the store with me. Sometimes he would follow me, other times he wouldn't and would only come to work close to the starting time.

When he does talk to you, he is always repeating himself and spending several days telling you the same thing. We get a little bored when he does that often. He seems to live in his own world.

He often says that he will go to work at the airport. Maybe he interviewed at the airport before interviewing with us. The airport didn't want him, which may be the reason he really wants to go to work there. Whenever he has time, he will go to the airport and hang out there. He took out his cell phone once and showed us pictures of airplanes he had taken at the airport. There's a bus with a stop in front of his house going around the airport, and he would take that bus to go and hang out at the airport. When he came back from annual leave, I asked him, "QJ, where did you go for fun during the 3 days?" And he said, "Manager, I didn't go anywhere except around the airport."

I really don't think his parents are doing the best job taking care of him. But I might have been nosy because this is just stuff I've heard. He has an older sister, and his parents don't seem to care what he does. Sometimes when he wasn't doing well at work, I would call his family. No one could talk to me in the morning because there was something going on at home, and no one had time in the afternoon because his mom probably went somewhere to play mahjong. Eventually someone called me back after dinner, around six or seven. But by that time I was already off work and busy at home, so I had no time to go into detail with his family about him.

\section{Interview with Mr. QJ}

Interviewee: Mr. QJ

Interviewer and writer: Xinhui Chen 
Interview date: December 2, 2016

Interview place: Restaurant where QJ works

The interviewer asked QJ whether he was willing to be interviewed. He shook his head and said "No." With help from co-worker D (who told QJ that the interviewer was not a reporter but another co-worker), QJ agreed to the interview. Throughout the interview, QJ avoided looking directly at the interviewer and kept his eyes fixed to the left of the interviewer.

Q: How many years ago was it when you started working here?

QJ: I started on December 22, 2011.

Q: How did you find out there were job openings here?

QJ: On the Internet on the computer, a public recruitment site for Shanghai.

Q: Did your parents go with you to the job interview?

QJ: No, that wasn't the case.

Q: So you went to the interview on your own?

QJ: Right.

Q: Were you nervous during the first interview?

QJ: Yeah.

Q: Do you remember what questions were asked during the interview?

QJ: No, I don't.

Q: Do you think your co-workers are nice?

QJ: No, not at all.

Q: Do they talk to you?

QJ: No.

Q: What do you do at work?

QJ: I'm a dish washer.

Q: I saw you play on your cell phone back there. What did you do on the phone?

QJ: I didn't. (Silence and refusal to answer)

Q: Which bus did you take to come to work today?

QJ: No. 991.

Q: When do you get off work today?

QJ: Eight.

Q: Which bus will you take to go home?

QJ: No. 991.

Q: Is it tiring for you to wash dishes?

QJ: Washing dishes, it's not too bad. I get busier sometimes on Friday, Saturday, and Sunday.

Q: I heard that there's an older lady who comes and helps you with the dishes on Saturday and Sunday, is that right?

(No reply)

Q: Which day of the week do you have off?

QJ: I have every Monday off and work from Tuesday through Sunday.

Q: So you work 6 days a week.

QJ: I work 6 days and have 1 day off.

Q: When do you usually start work and get off work? 
QJ: I start at 11 a.m. Tuesday through Friday, and the same on Saturday and Sunday. (Correcting himself) 11 a.m. Tuesday through Friday. As for Saturday and Sunday, no, let me think. (Shaking his head) I start work at 11 a.m. Tuesday through Friday, and at 10:30 a.m. on Saturday and Sunday.

Q: What about getting off work? Is it 8 p.m. every day?

QJ: Eight Tuesday through Friday and eight-thirty on Saturday and Sunday. Eightthirty in the evening, I mean.

Q: Do you get busy on Saturday and Sunday?

QJ: Yeah.

Q: Do you feel tired?

QJ: It's not too bad.

Q: How many hours do you usually wash dishes on Saturday and Sunday?

QJ: What?

Q: How many baskets of dishes do you have to wash?

QJ: Sometimes it gets really busy on Friday night.

Q: What do you usually do when you have Monday off?

QJ: I stay home.

$\mathrm{Q}$ : To play on the computer?

QJ: Yes.

Q: What do you play on the computer?

QJ: What?

Q: Do you play computer games?

QJ: I watch news and videos.

Q: Do you use WeChat on your phone?

QJ: No.

Q: How do you chat with your family then?

QJ: My parents don't know how to get on the Internet.

Q: How do you chat with your friends then?

QJ: I don't chat. I don't have friends.

$\mathrm{Q}$ : Which co-worker are you close to?

QJ: No one. There has never been anyone.

Q: Did you have good friends when you were young?

QJ: When I was young, my elementary school classmates loved me.

Q: Did you play with them after school?

QJ: After school?

Q: Did you go home with your classmates after school?

QJ: We went home together.

Q: Did you all live close to each other?

QJ: Yes. I originally lived in the direction of Pudong Airport, but the government relocated us in 1996.

Q: And that's when you moved to where you live now?

QJ: Shiwan, I live in Shiwan now.

Q: Have you kept in touch with your old classmates?

QJ: No. They all have jobs and kids, so it's different now. Having kids and jobs makes it all different. They are married. (Looking very sad) 
Q: Is there anything at work that makes you happy?

QJ: (Taking a while to answer) I have nothing to be happy about, nothing at all.

Q: I heard that you really like listening to music, right?

QJ: Right.

Q: What music do you normally listen to?

QJ: Little Apple.

Q: Can you sing it?

QJ: No, I am learning.

Q: Do you go and hang out at the airport when you have time?

QJ: I miss my old home.

Q: The manager just told me that you would go and take pictures of the airplanes, is that right?

QJ: Right.

Q: You really like taking pictures, do you?

QJ: I take pictures at the airport. I don't go anywhere else. I only go to Pudong Airport.

Q: Do you go there on your own?

QJ: No. When I was going to school as a kid, I had to walk a long way. I still remember it very clearly.

Q: On Mondays, do you go out for fun on your own?

QJ: I work triple-pay OT on New Year's Day, during Chinese New Year, also on Tomb-Sweeping Day, Labor Day, Dragon Boat Festival Day, and National Day.

Q: Do you work even on holidays?

QJ: I get triple pay, there's triple-pay OT on holidays.

$\mathrm{Q}$ : You have annual leave, right?

QJ: I did take annual leave.

Q: Did you take it this year?

QJ: I did.

Q: Did you go anywhere for fun during those 3 days?

QJ: I stayed home and went to Pudong Airport for fun.

$\mathrm{Q}$ : Your job is to wash dishes. Do you think you are doing a good job?

QJ: I also take out the trash.

Q: Do you think you are doing a good job?

QJ: Not really.

$\mathrm{Q}$ : Do you remember the previous managers?

QJ: Manager W.

Q: Of all the previous managers, which one was particularly nice to you?

QJ: They were all the same.

Q: What did they usually talk to you about?

QJ: Nothing.

Q: At work, you are on break from 3 to 5 p.m. What do you normally do during the break?

QJ: I sleep. 
Q: Will you play on your cell phone?

QJ: I play on my cell phone and sleep.

Q: On the days you go to work, when do you get up?

QJ: Whenever my alarm goes off.

Q: What time do you set the alarm for?

QJ: Seven.

Q: So you go to work immediately after brushing your teeth, washing your face and having your breakfast?

QJ: I start work at 11 a.m. and I take the Carrefour shuttle bus to go to work.

Q: When do you get on the Carrefour shuttle bus in front of your house?

QJ: I get on at 8:30 a.m.

Q: When do you arrive here?

QJ: About 9 a.m. The bus leaves at eight from Carrefour, eight in the morning.

Q: So what do you do in between?

QJ: I hang out at Carrefour. Carrefour.

Q: You take the No. 991 bus to go home. When do you get home?

QJ: Very late sometimes because of traffic. There is traffic sometimes because of road construction.

Q: What time is the latest you get home if there is traffic?

QJ: I am not sure.

Q: What time do you go to sleep at night?

QJ: Ten at night.

Q: Who taught you how to use the computer?

QJ: I started using the Internet in 2003.

Q: How did you learn how to use the computer?

QJ: I was playing in the Internet bars back then.

Q: Do you have a computer at home now?

QJ: I do now. I didn't have one before.

Q: Did you buy the computer yourself?

QJ: My parents bought it.

Q: In which year did they buy it?

QJ: In December 2014.

\section{Observation of QJ at Work}

Observation date: December 2, 2016

Observation place: Restaurant where QJ works

Observer and writer: Xinhui Chen 


\begin{tabular}{|c|c|c|}
\hline Time & What QJ did & Remarks \\
\hline 10:45-11:00 & $\begin{array}{l}\text { Arrived at the restaurant and changed } \\
\text { into work clothes }\end{array}$ & Workday started at 11 a.m \\
\hline 11:00-11:10 & $\begin{array}{l}\text { Helped co-worker wipe chopsticks } \\
\text { and forks }\end{array}$ & His main job is to wash dishes \\
\hline 11:10-11:20 & $\begin{array}{l}\text { Waited in the kitchen since there were } \\
\text { no dishes to wash }\end{array}$ & \\
\hline 11:20-12:00 & $\begin{array}{l}\text { Rested on a bench in the kitchen since } \\
\text { there were no dishes to wash }\end{array}$ & \\
\hline 12:00 & Cleaned up the dish-washing room & \\
\hline 12:10 & Rested on a bench in the kitchen & \\
\hline 12:40 & Rested on a bench in the kitchen & \\
\hline 13:00 & Rested on a bench in the kitchen & \\
\hline 13:06 & $\begin{array}{l}\text { Was summoned by a co-worker to the } \\
\text { lobby to move a large basket full of } \\
\text { plates, bowls, and glasses yet to be } \\
\text { washed }\end{array}$ & \\
\hline 13:09 & $\begin{array}{l}\text { Moved the basket to the dish-washing } \\
\text { room and started washing }\end{array}$ & \\
\hline $13: 30$ & $\begin{array}{l}\text { Finished washing and sat on a chair in } \\
\text { the back }\end{array}$ & \\
\hline 13:45 & $\begin{array}{l}\text { Started washing dishes that } \\
\text { co-workers had just brought in }\end{array}$ & \\
\hline 14:00 & $\begin{array}{l}\text { Finished washing and left through the } \\
\text { back door }\end{array}$ & $\begin{array}{l}\text { None of the co-workers knew where } \\
\text { he went }\end{array}$ \\
\hline 14:40 & $\begin{array}{l}\text { Brought back a snack and sat by a } \\
\text { table off the center of the lobby to } \\
\text { play on his phone }\end{array}$ & Two co-workers sat at another table \\
\hline 15:00 & Slept with elbows on the table & \multirow[t]{4}{*}{ QJ's break time was 15:00-17:00 } \\
\hline 16:00 & Slept with elbows on the table & \\
\hline $16: 36$ & Slept with elbows on the table & \\
\hline 16:46 & Got up and walked to the kitchen & \\
\hline 17:00 & $\begin{array}{l}\text { Started running water and washing } \\
\text { dishes }\end{array}$ & \\
\hline $17: 10-17: 23$ & Was interviewed & \\
\hline $17: 32$ & $\begin{array}{l}\text { Washed a pan cover, shook it dry, and } \\
\text { put the cover back }\end{array}$ & \\
\hline 18:05 & $\begin{array}{l}\text { Filled a big plastic box with water and } \\
\text { poured the water out }\end{array}$ & \\
\hline 18:08 & Left the kitchen & \\
\hline 18:29 & $\begin{array}{l}\text { Played on his phone outside the back } \\
\text { door }\end{array}$ & \\
\hline
\end{tabular}


(continued)

\begin{tabular}{l|l|l}
\hline Time & What QJ did & Remarks \\
\hline $19: 02$ & $\begin{array}{l}\text { Gave the washed bowls to his } \\
\text { co-worker to put on the shelf. Went to } \\
\text { the dining area to collect dirty bowls, } \\
\text { plates, and glasses }\end{array}$ & \\
\hline $19: 06$ & $\begin{array}{l}\text { Stood in front of the sink to wash } \\
\text { dishes }\end{array}$ & \\
\hline $19: 36$ & $\begin{array}{l}\text { Took out trash and put in a new trash } \\
\text { bag }\end{array}$ & \\
\hline $19: 48$ & $\begin{array}{l}\text { An older female co-worker and QJ } \\
\text { stood at two different sinks to wash } \\
\text { dishes. QJ was very slow-paced and } \\
\text { spent a very long time washing one } \\
\text { single bowl. QJ put the washed bowl } \\
\text { in a draining basket next to him }\end{array}$ & At peak time, both the female \\
& $\begin{array}{l}\text { Washed dishes on his own and put the } \\
\text { washed dishes in the draining basket }\end{array}$ & \\
\hline $19: 52$ & $\begin{array}{l}\text { Organized washed spoons before } \\
\text { putting them in the drawer }\end{array}$ & \\
\hline $19: 58$ & $\begin{array}{l}\text { Took the container he had brought his } \\
\text { meals in from home, took off his } \\
\text { apron and got ready to clock out }\end{array}$ & \\
\hline $20: 02$ &
\end{tabular}

Translated by Cissy Zhao

Edited by Andy Boreham and Zijian Chen

Open Access This chapter is licensed under the terms of the Creative Commons Attribution 4.0 International License (http://creativecommons.org/licenses/by/4.0/), which permits use, sharing, adaptation, distribution and reproduction in any medium or format, as long as you give appropriate credit to the original author(s) and the source, provide a link to the Creative Commons license and indicate if changes were made.

The images or other third party material in this chapter are included in the chapter's Creative Commons license, unless indicated otherwise in a credit line to the material. If material is not included in the chapter's Creative Commons license and your intended use is not permitted by statutory regulation or exceeds the permitted use, you will need to obtain permission directly from the copyright holder. 